\title{
Indícios de uma euro-futebolização no Sul do Brasil
}

\author{
Evidence of a Euro-footballing in Southern Brazil \\ Rodrigo Koch \\ Universidade Estadual do Rio Grande do Sul, São Francisco de Paula/Brasil \\ Doutor em Educação (Cultura Juvenis), UFSM \\ prof.koch.rodrigo@gmail.com
}

\begin{abstract}
RESUMO: Descrição da cultura juvenil futebolizada na Região das Hortênsias, especialmente, de Canela/RS, com traços muito próximos do que Giulianotti (2012) caracteriza como o torcedor pós-moderno ou flâneur. 0 estudo utiliza metodologias pós-estruturalistas; sendo que neste recorte são apresentados dados de pesquisas bibliográficas, quantitativos e qualitativos, a partir da aplicação de um questionário seguido de entrevistas com inspiração etnográfica. 0 objetivo foi compreender o processo contemporâneo de futebolização e como este se relaciona com a construção das identidades juvenis. A futebolização dos jovens produz um sujeito com poucos vínculos com os clubes de futebol locais, pois são muito mais interessados no sucesso de agremiações e celebridades estrangeiras e/ou europeias da modalidade.
\end{abstract}

Palavras-Chave: Juventude; Futebolização; Identidade; Região das Hortênsias.

ABSTRACT: Description of the youth culture footballed in the Hortênsias Region, especially, of Canela/RS, with very close traits of what Giulianotti (2012) characterizes as the fan postmodern or flâneur. The study uses poststructuralist methodologies; being that in this clipping are presented data of bibliographical, quantitative and qualitative researches, from the application of a questionnaire followed by interviews with ethnographic inspiration. The objective was to understand the contemporary process of footballing and how it relates to the construction of youth identities. The footballing of young people produces a subject with few ties to local football clubs and much more interested in the success of foreign and/or European associations and celebrities of the sport.

KEYwoRDS: Youth; Footballing; Identity; Hortensias Region. 


\section{INTRODUÇÃO}

Este texto é um recorte da pesquisa de doutorado intitulada Identidades em construção: um olhar sobre a futebolização da juventude no Ensino Médio, desenvolvida na Universidade Federal de Santa Maria, no Rio Grande do Sul, no período de 2015-2018. O processo contemporâneo da futebolização vem sendo pesquisado entre crianças e jovens na escola desde 2011, com atenções maiores para as regiões Metropolitana do Rio Grande do Sul (municípios de Porto Alegre e Gravataí) - nos anos de 2011 e 2012, no mestrado - e das Hortênsias (cidades de Canela, Gramado e São Francisco de Paula) - nesta segunda etapa.

Trabalhei com o seguinte problema de pesquisa: em que medida o processo contemporâneo de futebolização se relaciona com a construção das identidades juvenis nas escolas públicas e privadas da Região das Hortênsias no Ensino Médio? Neste artigo, apresento dados bibliográficos, quantitativos e qualitativos da Região das Hortênsias, coletados durante os anos de 2015, 2016 e 2017, que podem dar indicativos sobre o comportamento das culturas juvenis da contemporaneidade encontradas e vivenciadas neste espaço. Inicialmente descrevo, de forma breve, o fenômeno pós-moderno da futebolização, para situar o leitor, e depois apresentarei os demais aspectos e alguns "achados" que compõem esta pesquisa.

\section{O FENÔMENO PÓS-MODERNO DA FUTEBOLIZAÇÃO}

A futebolização ${ }^{1}$ - fruto da globalização a partir do futebol espetacularizado e mercantilizado, principalmente a partir dos anos 1990 - está imersa em um campo fluído que apresenta variações de tempos em tempos (sem que haja uma norma para cada período temporal) e, por isso, se transforma e se transfigura em cada espaço que penetra e a cada instante, adquirindo também contornos locais. Portanto, na construção do conceito ou na descrição do fenômeno globalizador, utilizei referenciais teóricos de Zygmunt Bauman a respeito da modernidade

\footnotetext{
${ }^{1} \mathrm{KOCH}$. Marcas da futebolização na cultura e na educação brasileira; $\mathrm{KOCH}$. Identidades em construção: um olhar sobre a futebolização da juventude no Ensino Médio.
} 
líquida, ${ }^{2}$ de Gilles Lipovetsky sobre o mundo leve ${ }^{3}$ e, de Stuart Hall, ${ }^{4}$ referente ao fenômeno da globalização, para contextualizar a sociedade contemporânea, de Nestor Garcia Canclini, 5 sobre hibridação, na tentativa da construção dos indivíduos que constituem tal sociedade, e de Guy Debord sobre a sociedade do espetáculo ${ }^{6}$ e a passagem para a sociedade "midíocre", nas análises de Juremir Machado da Silva. ${ }^{7}$ Utilizei também outros conceitos desses mesmos autores e outros autores que contribuem para descrever o processo pós-moderno da futebolização. Se não há um esporte pós-moderno, no mínimo há um esporte neomoderno que requer novas e constantes análises.

Não considero a futebolização um conceito e sim um fenômeno e/ou processo. Penso que a mesma pode também ser considerada uma pedagogia cultural. Desde a emergência dos Estudos Culturais - em Birmingham, na Inglaterra - a pedagogia passou a ser entendida como um mecanismo de ensinamento ou difusão de modos de ser e pensar, ou seja, a pedagogia não se limita a práticas escolares explícitas ou institucionalizadas: ela está na TV, em filmes, jornais, revistas, anúncios, videogames, aplicativos, brinquedos, e também nos esportes. ${ }^{8} 0$ conceito ganhou espaço em pesquisas acadêmicas nas áreas da Educação e Comunicação. Andrade e Costa (2015), ${ }^{9}$ ao buscarem elementos sobre a emergência do conceito de pedagogias culturais, destacam que uma das principais características do imperativo pedagógico contemporâneo é a existência de relações de ensino e aprendizagem em diferentes espaços sociais regulados pela cultura. Em resumo, uma pedagogia cultural pode ser qualquer mecanismo midiático ou social capaz de ensinar algo para alguém. Os exemplos mais comuns na contemporaneidade seriam os programas de TV ou os aplicativos de smartphones. Portanto, o fenômeno da futebolização também pode se encaixar no

\footnotetext{
2 BAUMAN. Modernidade líquida.

3 LIPOVETSKY. Da leveza: rumo a uma civilização sem peso.

${ }^{4}$ HALL. A centralidade da cultura.

${ }^{5}$ CANCLINI. Culturas híbridas.

${ }^{6}$ DEBORD. A sociedade do espetáculo.

${ }^{7}$ SILVA. A sociedade midíocre.

8 STEINBERG. Kindercultura: a construção da infância pelas grandes corporações.

9 ANDRADE; COSTA. Usos e possibilidades do conceito de pedagogias culturais nas pesquisas em estudos culturais em educação.
} 
conceito de pedagogia cultural, pois o mesmo está imerso na cultura e sem dúvida alguma produz seus ensinamentos.

É importante, ainda, relembrar que o futebol se tornou, no último século, o principal esporte de massa do mundo, tendo espaço de destaque nos diversos canais da mídia em vários países, fato que ajudou e provocou a construção do próprio termo futebolização. 0 futebol agrega o povo, dando sentido de identidade e nação. É esporte, lazer, produto e cultura ao mesmo tempo. ${ }^{10}$ De acordo com Giulianotti (2010),11 o futebol é uma das grandes instituições culturais, como a educação e a mídia, que forma e consolida identidades nacionais no mundo inteiro.

\section{ASPECTOS METODOLÓGicos}

Esta pesquisa trata-se de um estudo descritivo de uma cultura juvenil, com suas linguagens e hábitos, como também das manifestações materiais de suas atividades. Utilizei questionário (em anexo) e entrevistas como ferramentas da pesquisa. Segundo Bauer e Gaskell (2002), ${ }^{12}$ as entrevistas podem ocorrer com um único respondente (em profundidade), ou com vários respondentes (grupo focal). Neste estudo, portanto, foram utilizadas as duas possibilidades, tanto com alunos como com alguns professores. Seguindo orientações que o autor destaca, realizei “conversações continuadas menos estruturadas, porém com inspirações na observação participante, ou etnografia, onde a ênfase é mais em absorver o conhecimento local e a cultura por um período de tempo mais longo".13

Nas análises dos achados da pesquisa utilizei a Análise do Discurso - prática e campo da linguística e da comunicação especializado em analisar construções ideológicas presentes em um contexto. A análise textual discursiva, utilizada em áreas como a Comunicação, a Psicologia, a Educação e o Serviço Social, pode ser compreendida como um processo de auto-organização, de construção e de compreensão em que novos entendimentos emergem de uma sequência recursiva de três componentes: desconstrução dos textos (ou discursos) do corpus, a

\footnotetext{
${ }^{10}$ ALABARCES. Cidadania e narrativas nacionais do futebol argentino contemporâneo.

${ }_{11}^{11}$ GIULIANOTTI. Sociologia do futebol.

12 BAUER; GASKELL. Pesquisa qualitativa com texto, imagem e som.

${ }^{13}$ BAUER; GASKELL. Pesquisa qualitativa com texto, imagem e som, p. 64.
} 
unitarização; estabelecimento de relações entre os elementos unitários, a categorização, e o captar do novo emergente em que a nova compreensão é comunicada e validada. ${ }^{14}$

\section{A CONDIÇÃO FLÂNEUR DO TORCEDOR PÓS-MODERNO}

No aclamado mundo de diversidades e policultural contemporâneo nos defrontamos diariamente com identidades mutantes, que apresentam variadas formas de acordo com os sujeitos que nelas trafegam ou que simplesmente são respingados ou contaminados pelas suas condições virais das sociedades conectadas e desconectadas. Falar, por exemplo, de identidade nacional na contemporaneidade pode ser algo penoso e complicado para muitos. Tal identidade tinha (ou tem) como objetivo traçar as fronteiras entre "nós" e "eles". No entanto, a tarefa é árdua, pois, diante dos processos e fenômenos globalizadores, as essencialidades ditas puras caem por terra e as identidades cada vez mais parecem "colchas de retalhos" que carregam as marcas das vivências e experiências de cada indivíduo, com as afiliações selecionadas ou indicadas para cada um de nós. Os grupos que tentamos encontrar ou estabelecer tendem a ser eletronicamente mediados como frágeis totalidades virtuais, em que é fácil entrar e também ser abandonado. 0 patriotismo, um dos ativos mais preservados pelas nações em épocas passadas, foi transferido para as forças de mercado e por elas remodelado. Hoje é possível, por exemplo, comprar uma cidadania catalã e, em poucas horas, ser um torcedor do Barcelona como qualquer cidadão mundial. Assim se sucede em outras categorias e continuará a se suceder também no futebol sempre que algum clube ou celebridade estiver em evidência.

Bauman ${ }^{15}$ se refere às comunidades "guarda-roupa", ou seja, grupos que "vestem" determinados fenômenos culturais por curtos instantes. Um dos exemplos citados pelo autor é as empolgantes partidas de futebol. Estes grupos que se formam por alguns momentos fugazes, nos mais variados espaços de convivência (ruas, bares, festas, escolas, redes sociais...), não apresentam qualquer

\footnotetext{
${ }^{14}$ MORAES. Uma tempestade de luz.

${ }^{15}$ BAUMAN. Identidade.
} 
relação afetiva-emocional que os una fora daquela circunstância. São "nações" imaginadas movidas por qualquer evento espetacular ou escandaloso, construídas, desconstruídas e, por vezes, reconstruídas mais rapidamente do que são agrupadas. Apesar de muitos membros individuais diferirem, todos compartilham atributos essenciais que constituem sua identidade de "nação". Neste ponto, a igualdade supera a diferença. Após vivenciar a sensação do momento unificador, cada elemento retoma sua identidade individual para posteriormente - seja de forma imediata ou não - buscar uma nova identidade coletiva. A comunidade é imaginada porque a maioria de seus membros nunca se conheceu, porém nas mentes de cada um vive uma imagem de comunhão. ${ }^{16}$ No entanto, isto não significa que não haja comunidades "verdadeiras" que podem se justapor sobre as imaginadas. ${ }^{17}$ Mas, tal fenômeno também causa suas angustias e sofrimentos, pois a facilidade do desengajamento e do rompimento não reduz os riscos, apenas os distribui junto com as ansiedades que exalam não só nos adultos, mas, principalmente, em jovens e também em crianças.

No Brasil não só o futebol evoluiu nas últimas décadas, os torcedores e as torcidas também. De uma atividade familiar de finais de semana, os atos dos agrupamentos se transformaram em festas competitivas através das torcidas organizadas, manifestações de poder, violência e status social e, mais recentemente, foram significadas pela condição do torcedor-consumidor. Atualmente, torcer não é considerado apenas o ato de acompanhar uma equipe e apoiá-la contra o adversário. Torcer também é consumir a mercadoria futebol, pois “[...] nas sociedades pós-modernas, a identificação com o coletivo é voluntária e transitória, refletindo formas frias, pós-emocionais, de identificação pessoal". ${ }^{18}$ No futebol talvez não exista mais a necessidade da identificação local, e parece muito mais interessante para os jovens adquirir a identidade dos seus ídolos, que hoje

\footnotetext{
${ }_{17}^{16}$ ANDERSON. Comunidades Imaginadas, p. 32.

${ }^{17}$ Comunidades imaginadas é um conceito cunhado por Benedict Anderson. Uma comunidade imaginada é diferente de uma comunidade real pois não se baseia em interação face à face de seus membros, e, por razões práticas, não pode fazê-lo: Anderson chega a mencionar que nada maior que um vilarejo pode ser uma comunidade real, já que é impossível que todos seus membros se conheçam. Nação é um exemplo de comunidade socialmente construída, imaginada por pessoas que percebem a si próprias como parte de um grupo. Benedict Anderson definiu nação como "uma comunidade política imaginada - e imaginada tanto como limitada quanto soberana por excelência".

${ }^{18}$ GIULIANOTTI. Fanáticos, seguidores, fãs e flâneurs, p. 13.
} 
estão espalhados pelo mundo. Portanto, passou a ser comum enxergarmos mais camisetas de clubes de futebol internacionais, principalmente europeus, do que de equipes locais em diversas metrópoles brasileiras e, isto indica que os jovens estão mais vinculados às personagens, celebridades, ídolos do futebol e grandes e ricos clubes estrangeiros da atualidade.

Dentro dos processos globalizadores - nos quais se encontra a futebolização - e que tentam estabelecer padrões mundiais, é necessário marcar estas questões mais especificamente, pois o futebol faz parte da cultura local e nacional em diversos países e da condição social da leveza-distração. Paradoxalmente, na contemporaneidade, a maioria absoluta dos torcedores somente acompanha o espetáculo futebolístico pela mídia e muitos são mais fiéis aos seus ídolos do que os que têm a possibilidade de estarem in loco observando todo o movimento cultural gerado pelo esporte. É possível identificar, através das manifestações culturais produzidas pelo esporte mais popular do mundo, grupos extremamente ligados por valores semelhantes e que se comportam de maneira similar mesmo à distância, sem que nunca tenham tido contato direto.

Há pesquisadores que ainda defendem uma fidelidade clubística dos torcedores de futebol, ou seja, não apostam na(s) possibilidade(s) de troca(s) de equipes, times, ou clubes ao longo dos próximos anos.

É possível considerar um sujeito plenamente socializado para o futebol de espetáculo quando ele tiver experimentado as oscilações decorrentes do fato de pertencer a um clube de futebol. Seria dizer o mesmo afirmando-se que um torcedor sentirá a pleno o que significa torcer quando experimentar trocar de clube e perceber que isso é demasiadamente custoso ou, ainda, tentando gostar de outro, sentir-se tocado pelo antigo clube do coração. A fidelidade é estruturante no clubismo e seu amálgama é afetivo - por isso tão consistente e difícil de ser verbalizada pelos torcedores. ${ }^{19}$

Não considero que Damo ${ }^{20}$ esteja de todo equivocado porque condições modernas e pós-modernas se confundem em tempos contemporâneos, líquidos e leves. 0 próprio pesquisador admitiu adotar hipóteses arrojadas para defender sua

\footnotetext{
${ }^{19}$ DAMO. Futebol, engajamento e emoção, p. 74.

${ }^{20}$ DAMO. Futebol, engajamento e emoção.
} 
tese, e em textos seguintes esclareceu que "nem todos os que se declaram torcedores de futebol são do tipo "fanático", "doente", "maluco", enfim, aqueles para quem o clubismo efetivamente importa". ${ }^{21}$ Vejamos como a circunstância é tratada por outros estudiosos da questão das identidades no futebol para chegarmos onde pretendo. Giulianotti ${ }^{22}$ dividiu os aficionados do futebol em quatro categorias de torcedores na contemporaneidade: fanáticos, fãs, seguidores e flâneurs. Não quero aqui determinar qual destas categorias está em maior número e, muito menos apontar qual destes comportamentos seria o mais adequado. 0 que chama atenção nestes apontamentos é que encontramos sujeitos mais vinculados à modernidade e, outros já em transição ou aderidos aos processos pós-modernos. Portanto, de acordo com Giulianotti, ${ }^{23}$ as características dos torcedores contemporâneos são as seguintes:

Fanático: torcedor clássico, com investimento pessoal e emocional de longo prazo; demonstra apoio a seu clube de múltiplas formas; o indivíduo possui uma relação com o mesmo que se assemelha a relação com a família; torce por um único clube a vida inteira;

Seguidor: torcedor/telespectador que segue mais de um clube, mantendo o hábito do futebol; tem diversas ligações para manter sua paixão pelo esporte;

Fã: vivencia o clube, suas tradições, e seus maiores jogadores à distância, com relações baseadas no mercado; a relação com o clube é autenticada através do consumo de produtos a ele relacionados; são motivados a produzir relações não recíprocas;

Flâneur: interações com o futebol através da mídia (especialmente televisão e internet); busca uma multiplicidade de experiências no futebol; adota postura afastada aos clubes; lealdades nacionais podem ser trocadas com base no sucesso competitivo ou na identificação mediada com grandes celebridades; seu habitat natural é a "arena virtual", buscando sensações do futebol representadas pela televisão, internet e, também pelos games; há ocasiões em que se congregam, simulando a paixão pelo clube de futebol parecendo fanáticos; a identidade é baseada no movimento constante, cada vez mais em termos virtuais, mudando de clube como se muda de canal de televisão; buscam sensações, excitação, e assim observam diversos clubes, jogadores e nações. ${ }^{24}$

${ }^{21}$ DAMO. Futebol, engajamento e emoção, p. 88.

22 GIULIANOTTI. Fanáticos, seguidores, fãs e flâneurs.

${ }^{23}$ GIULIANOTTI. Fanáticos, seguidores, fãs e flâneurs.

${ }^{24}$ GIULIANOTTI. Fanáticos, seguidores, fãs e flâneurs, p. 20-27. 
Percebo que a última categoria definida por Giulianotti, ${ }^{25}$ dos flâneurs, é a que a maioria dos jovens torcedores das grandes metrópoles, mas não só delas, se insere na atualidade. Observo que vivemos em sociedades de torcedores múltiplos, ou seja, com as quatro categorias, mas talvez em poucos anos poderemos ter uma parcela maior de flanadores. Giulianotti ${ }^{26}$ também utiliza o termo "torcedores nômades" para definir esta condição. Considero que este novo comportamento poderá conduzir o mercado do futebol para fortes mudanças em pouco tempo. Portanto, partindo do princípio de que uma torcida de futebol constitui uma "nação" - palavra corriqueiramente convocada pela mídia para definir o agrupamento de aficionados por uma mesma agremiação esportiva -, proponho discutir as novas configurações de "nações" futebolizadas na pós-modernidade, com especial atenção para os flâneurs.

Nenhum torcedor de futebol encontra-se hermeticamente fechado, de modo a impedir a entrada do novo sistema de marketing. A complexidade das relações econômicas do futebol significa que todos os torcedores estão vinculados a esse processo de mercantilização. [...] As classes operárias e as classes médias baixas são ligadas às práticas culturais e identidades (inclusive o time de futebol da comunidade) "locais". As classes médias e as altas tendem a ser mais móveis, geográfica e intelectualmente, e mais "cosmopolitas" em seus compromissos, sustentando um interesse em times de futebol grandes, mas movendo-se para outros lados quando convém. ${ }^{27}$

Podemos considerar uma torcida de futebol como mais uma das tantas "nações imaginadas" da pós-modernidade. Outras manifestações grupais da sociedade contemporânea, como a religião e a política - com as diversas igrejas e partidos -, também assumem configurações de "nação" em tempos pós-modernos. O que reforça este sentimento de "nação" vinculado ao futebol é que "[...] ao se identificar com uma determinada equipe, o torcedor se opõe aos torcedores das outras equipes", ${ }^{28}$ e isso contribuiu para a identidade do sujeito neste novo espaço. Em tempos de crises políticas acentuadas e de um enorme sincretismo religioso, o

\footnotetext{
${ }^{25}$ GIULIANOTTI. Fanáticos, seguidores, fãs e flâneurs.

${ }^{26}$ GIULIANOTTI. Sociologia do futebol.

27 GIULIANOTTI. Sociologia do futebol, p. 138-139.

${ }^{28}$ LOUZADA. Identidade e rivalidade entre os torcedores de futebol da cidade de São Paulo, p. 5.
} 
futebol parece - ainda que artificialmente - dar mais solidez e esperança ao indivíduo que persegue uma identidade e sente necessidade de fazer parte de uma "nação".

Para avançarmos nas discussões torna-se importante fazer um questionamento: Como são estabelecidos os grupos sociais dos torcedores de um determinado clube? Há poucas décadas os pais tratavam de doutrinar os filhos para que seguissem o mesmo gosto clubístico paterno ou familiar (eram torcedores fanáticos), pois causava desconforto ter um torcedor adversário convivendo no mesmo lar. Tal situação não mudou completamente, mas o contrário já não é mais visto com tanta estranheza em períodos de globalização e novas configurações familiares e de torcedores. Segundo Giulianotti, ${ }^{29}$ esta nova classe de "pós-torcedores" é essencialmente constituída também pela nova classe média global, que ao contrário da burguesia tradicional, abraça a cultura popular em vez de rejeitá-la e, frequentemente mistura futebol e música (rock) com interesses por literatura e artes cênicas, algo comum entre os jovens. $\mathrm{Na}$ contemporaneidade, o vínculo com o clube pode ocorrer pela força midiática do ídolo. Os melhores exemplos da atualidade são os jogadores de futebol Cristiano Ronaldo, Neymar e Messi, que provocaram uma "onda" de novos torcedores do Real Madrid e do Barcelona, respectivamente, independente das cidades onde residem esses novos aficionados. As recentes trocas de clube de Neymar e Cristiano Ronaldo também devem provocar o surgimento repentino de torcedores do Paris Saint Germain, da França, e da Juventus, da Itália. O comportamento do torcedor é algo difícil de justificar e está ligado não só ao jogo em si, mas também à identificação que cada um tem com seu clube ou celebridade, ainda que esta não possa ser considerada essencial ou pura. Nos identificamos com uma equipe ou ídolo por questões e fatos que passam desapercebidos naquele instante "mágico" de união - pretensamente - eterna.

O torcedor está determinado a um circuito de consumo, onde o futebol é o último elo desta cadeia. Os jovens torcedores do futebol pós-moderno apresentam comportamentos renovados em relação aos posicionamentos que estávamos acostumados há menos de trinta anos, ou seja, até a década de 1980. Para ser

${ }^{29}$ GIULIANOTTI. Sociologia do futebol. 
torcedor de um time era necessário um vínculo identitário local, que remetesse aos costumes regionais, e também, frequentar o estádio em dia de jogos, ter a camiseta do time, conhecer os ídolos do presente e do passado, enfim, participar in loco das atividades desta "nação". Era raro encontrar torcedores do Inter ou do Grêmio, por exemplo, em outras regiões que não fossem habitadas por gaúchos ou colonizadas por estes. Da mesma forma, antes da entrada do novo milênio, era pouco comum ver camisetas do Barcelona, do Real Madrid, do Chelsea, do Bayern Munique, do Flamengo, do Corinthians, do Santos e tantos outros times de futebol circulando pelas ruas de Porto Alegre ou cidades do interior gaúcho. Hoje, é possível ser um torcedor apaixonado de qualquer clube do mundo sem nunca ter pisado no estádio desta agremiação, ou nem mesmo ter uma camiseta do time escolhido. Os vínculos surgem como consequência da intensa midiatização do futebol, com canais de tevê especializados na modalidade e que transmitem diariamente jogos, principalmente dos torneios europeus. Também há inúmeros artefatos ao alcance de crianças e jovens, como games, produtos esportivos - que se tornaram moda infantil e juvenil -, miniaturas de jogadores e outros acessórios futebolizados. A globalização proporcionou o surgimento de novas torcidas, principalmente de clubes europeus, nos mais longínquos cantos do planeta. Camisetas dos mais diversos clubes de futebol circulam pelas grandes metrópoles e até pelas pequenas cidades do interior, ainda que seja num passo mais lento e desigual.

As identidades futebolísticas não são mais fixas. Assim, temos hoje torcedores de apenas um clube, mas de vários clubes, ou seja, indivíduos que adotam múltiplas identidades no futebol, e que se permitem adotar lados contraditórios a cada semana ou a cada rodada de campeonato. Como destaca Hall, ${ }^{30}$ é muito pouco provável que a globalização destrua as identidades nacionais. É mais provável que produza, simultaneamente, novas identidades globais e novas identidades locais. Os torcedores, agora, são vistos como consumidores, em um cenário onde o público espectador não importa mais e sim o telespectador.

0 alvo principal das grandes marcas do futebol internacional passou a ser as torcidas ou torcedores infiéis, modelo no qual se encontra a categoria dos

\footnotetext{
${ }^{30}$ HALL. Sin garantías: trayectorias y problemáticas en estudios culturales.
} 
flâneurs. ${ }^{31} \mathrm{Na}$ contemporaneidade os veículos midiáticos mais produtivos em relação às identidades juvenis são a internet e, ainda, a televisão. Diariamente o público infantil e juvenil está em contato com mensagens e enunciados espetacularizados por esses meios que produzem as mais variadas sensações de pertencimento ou distanciamento, emoção ou aflição, simpatia ou antipatia, entre outros sentimentos relacionados às celebridades e marcas. 0 futebol - sendo um desses espetáculos midiáticos da contemporaneidade e ainda um espaço de demarcação de fronteiras, significados e pertencimento identitário - exerce forte presença e se apresenta como difusor de valores no cotidiano dessas crianças e jovens. Não podemos nos surpreender e não devemos mais exigir que as juventudes tenham um amor profundo por este ou aquele time de futebol, como ocorria há cerca de 30 anos atrás. Entre a nova geração, a troca constante das preferências clubísticas já está ocorrendo e poderá se intensificar em poucos anos. Prova disso são os comportamentos de crianças e jovens que a cada dia escolhem a camiseta de um clube ou de uma seleção que melhor lhes convém, ainda que mantenham simpatia por um time local, mas sem a necessidade de manter um laço eterno com qualquer um destes.

\section{INDÍCIOS DE UMA CULTURA JUVENIL EURO-FUTEBOLIZADA NO SUL DO BRASIL}

A partir das análises preliminares, ao encontrar os jovens futebolizados identificando os mesmos pelo que vestiam, conversavam, ou pela simples ação de praticar futebol (ou outra atividade que remetia ao mesmo) - apliquei questionário (em anexo) com objetivos específicos para entender o processo pósmoderno da futebolização antes de conduzir as entrevistas. Destaco, neste recorte, algumas das respostas coletadas nesta pesquisa.

Em média, os jovens assistem cerca de dois jogos de futebol por semana e, com base em outras questões, imagina-se que seja a maioria pela televisão ou pelas telas. Percebe-se também que o público masculino acompanha o futebol com maior frequencia e, que uma parcela pequena do segmento feminino pode passar mais

\footnotetext{
${ }^{31}$ GIULIANOTTI. Fanáticos, seguidores, fãs e flâneurs.
} 
dias sem assistir jogos de futebol. Poucas meninas acompanham mais de cinco partidas de futebol por semana, enquanto que a maioria dos meninos o faz. No entanto, quais competições assistem estes jovens é o que chama atenção, quando poderiam optar por mais respostas do que apenas um campeonato e/ou torneio. As principais preferências não chegam a surpreender, pois é natural que o Campeonato Brasileiro (90\%) seja o mais acompanhado pelos jovens, seguido da Taça Libertadores da América (82\%) - principal competição continental da América -, pois nos mesmos estão envolvidos os grandes clubes do cenário nacional. 0 destaque fica por conta da Champions League, ou Liga dos Campeões (80\%), competição que reúne os maiores e mais ricos clubes do futebol mundial (todos com sede na Europa) e, que para as juventudes do Brasil - com raríssimas exceções - só pode ser acompanhado pela mídia. Inclusive o índice de garotos que prefere a competição do velho continente é maior do que o número daqueles que seguem a Libertadores e, começa a se aproximar dos números do Brasileirão. A Liga Europa (48\%) - torneio para clubes do segundo escalão europeu, ou seja, aqueles que obtém colocações de destaque nos campeonatos nacionais, mas que não ocupam as primeiras posições - também está entre os cinco campeonatos preferidos pelos jovens futebolizados. Já entre as meninas, a Copa do Mundo, uma competição de seleções, tem a maior importância. Esta questão ainda põe em destaque o Campeonato Espanhol (33\%), como a segunda competição nacional preferida pelos jovens, muito provavelmente pela presença de Real Madrid e Barcelona, clubes que obtiveram as maiores conquistas nas duas últimas décadas no futebol mundial e que detinham os atletas que protagonizam a escolha do melhor jogador de futebol do mundo nos últimos anos: Cristiano Ronaldo e Messi, respectivamente. Chama atenção ainda que a Eurocopa, para o público masculino, é mais importante que outras competições como a Série B do Campeonato Brasileiro ou o Torneio de Futebol dos Jogos Olímpicos. Também merecem destaque nesta pergunta a Copa América (41\%) e o Campeonato Inglês (32\%) com índices significativos entre os meninos, mas com importância nula para as meninas. Saliento ainda que foi perguntado aos jovens quais os campeonatos e/ou torneios de futebol que acompanham, não sendo verificado aqui - de forma quantitativa - a ordem de preferência, ou seja, não foi questionado - por exemplo - 
se colocam a Champions League em ordem de importância acima dos campeonatos nacionais. Esta condição é apenas perceptível nas respostas das entrevistas realizadas com indivíduos desta cultura juvenil. Nas considerações destes jovens futebolizados, o futebol estrangeiro além de ser mais atrativo visualmente, ainda não apresenta tantas brigas e conflitos entre jogadores. Ou seja, há, para os jovens, uma cordialidade maior entre os rivais.

Não sei. 0 futebol, parece, que de fora tem um estilo mais diferente. [...] É uma mistura de gente de todo mundo num time só e faz um futebol bonito. Parece que não tem aquela "briga", sabe, do futebol brasileiro. Eu acho que é por causa disso que os jovens gostam bastante. (Leonardo, 18 anos, Escola Estadual de Ensino Médio Danton Correa da Silva, em 16 de agosto de 2016).

É realmente diferente né, futebol de lá e futebol daqui. A qualidade do treino é diferente. Basicamente tudo é diferente, até os estádios e a torcida. A torcida daqui é muito mais agressiva. Os jogos do Real Madrid não tem aqueles xingamentos como em um Gre-Nal. Aquelas "tretas", digamos. É mais clássico. (Luca , 16 anos, Colégio Marista Maria Imaculada, em 15 de maio de 2017).

Nas falas anteriores, mesmo sem saber ou conseguir explicar os reais motivos, os jovens - tanto meninos como meninas - mostram maior interesse no futebol europeu, como revelam, provavelmente, pela presença das celebridades da modalidade nas equipes e competições internacionais. Há também uma "admiração" pelo comportamento exigido para torcedores e atletas de futebol no cenário das competições europeias.

Os dados da questão seguinte são bastante interessantes e profícuos para as análises deste estudo. Por estarmos analisando o comportamento de jovens torcedores na região Sul do Brasil e em uma cidade (Canela/RS) próxima ${ }^{32}$ à capital do Rio Grande do Sul (Porto Alegre), é natural que a maioria dos entrevistados opte por Grêmio ou Internacional como seu clube de futebol preferido. Aqui o que chama atenção são características cada vez mais próximas do torcedor pós-moderno e afastadas da condição moderna. Pelos números, podemos observar que ainda há aqueles com vínculos mais afetivos com um único clube local (característica da modernidade) e, inclusive, esta situação está mais presente

${ }^{32}$ A distância entre Canela e Porto Alegre é de 135 quilômetros. 
no gênero feminino, com quase $20 \%$ (vinte por cento) das entrevistadas sendo torcedoras somente do Grêmio ou do Inter. 0 mais significativo é que a absoluta maioria dos jovens contemporâneos torce para um dos clubes com maior expressão no Estado e também adota outras agremiações, quase na totalidade estrangeiras. Também é curioso o fato de muitos, ao escolherem clubes fora da rivalidade Gre-Nal, optarem por seguir equipes que são rivais em território europeu. Nas respostas há uma certa parcela de jovens futebolizados que simpatiza, acompanha e também torce, ao mesmo tempo, por Real Madrid e Barcelona - rivais na Espanha e no futebol mundial contemporâneo -, Internazionale e Milan - clubes rivais da cidade de Milão, na Itália -, e/ou Manchester United e Manchester City - sediados ao norte da Inglaterra e anualmente candidatos aos títulos nacional e continental -, por exemplo, entre outras rivalidades estrangeiras. Segundo análises de Gurgel,33 há três pontos a serem considerados no cenário futebolístico mundial após a virada do milênio: a) o modelo atual provocou o enfraquecimento de todos os clubes que não fazem parte dos grandes torneios internacionais e consequentemente são exportadores de seus principais jogadores; b) a lógica transnacional dos superclubes está prejudicando a identificação nacional; e c) o aumento gradativo do comportamento xenofóbico de países imperiais na Europa como Itália, Espanha, Alemanha e Inglaterra. Sem excluir os pontos levantados e, em certa medida, concordando com as considerações feitas por Gurgel, ${ }^{34}$ vou mais adiante nesta situação de múltiplas escolhas por times de futebol dos jovens. Considero tais condições juvenis, como típicos comportamentos do torcedor flâneur, na busca por uma multiplicidade de experiências no futebol, onde as lealdades nacionais podem ser trocadas com base no sucesso competitivo ou na identificação mediada com grandes celebridades. Vejamos quais são (ou eram, pois o comportamento do torcedor pós-moderno é bastante volátil e fugaz) os clubes preferidos dos jovens futebolizados de Canela/RS através das respostas na pergunta seguinte do questionário e também das justificativas nas falas e discursos analisados durante este estudo.

\footnotetext{
${ }^{33}$ GURGEL. O futebol como agente da globalização.

${ }^{34}$ GURGEL. O futebol como agente da globalização.
} 
A cultura juvenil futebolizada se caracteriza por seguir e simpatizar mais de uma equipe de futebol. Geralmente acompanham um time "local", por influência familiar ou dos amigos e optam por outra(s) equipes(s), que estão em evidência na mídia pelas suas conquistas recentes ou pelas celebridades da modalidade que possuem em seus plantéis, casos evidentes na contemporaneidade de Real Madrid e Barcelona, que acabam dividindo a preferência dos jovens gaúchos com Grêmio e Internacional. $\mathrm{Na}$ soma dos números gerais, as equipes espanholas têm mais adeptos que a dupla Gre-Nal; fato que se explica pela seguinte situação: ninguém no Rio Grande do Sul é "autorizado" a torcer por Grêmio e Internacional simultaneamente, enquanto que o mesmo pode até ser considerado "normal" para as equipes estrangeiras. Portanto, muitos jovens optaram por responder, quando questionados sobre seu(s) clube(s) preferido(s), Grêmio (55\%) ou Internacional (38\%), mais Real Madrid (55\%), Barcelona (42\%) e outras equipes que também aparecem em destaque nas preferências, conforme gráfico 1.

Desde pequeno eu sempre gostava de ver futebol, só que gostava de ver de fora porque os times do Brasil não são muito bons, não tem grandes contratações e, então, o mercado de fora é melhor. Eu sempre gostei muito do Cristiano Ronaldo, não sei porquê. Sempre assisti aos jogos dele e torço pelo Real Madrid. (Paulo, 15 anos, Colégio Marista Maria Imaculada, em 23 de setembro de 2016).

Eu tinha preferência pelo Manchester City mas já caiu cedo. Eu vou torcer pelo Real [Madrid]. Para mim é o melhor time do mundo, não tem ... É um futebol incrível. Os "caras" tem um entrosamento que não dá para entender. É um time que já é certo que vai ganhar, mas tudo pode acontecer. (Leonardo, 18 anos, Escola Estadual de Ensino Médio Danton Correa da Silva, em 1ำ de junho de 2017).

Os únicos que eu torço é o Grêmio, o Barça e a seleção. 0 resto eu tenho [as camisetas] só por coleção. (Marcelo, 17 anos, Colégio Marista Maria Imaculada, em 29 de junho de 2017).

Em primeiro lugar o Inter né. Aí depois eu gosto do Real Madrid, eu gosto do Barcelona, mas eu torço realmente para o Inter. Jogadores eu admiro muito o Neymar, o Cristiano Ronaldo e o Messi, não são do Inter, mas o D'Alessandro não fica de fora. (Francesca, 16 anos, Colégio Marista Maria Imaculada, em 29 de junho de 2017).

Barcelona e Real Madrid eu acompanho, mas quando os dois jogam eu torço pelo Barcelona, pelo trio Messi, Neymar e Suárez. O Neymar é brasileiro. O Barcelona é um time bom e eu torço por eles. O Ronaldinho já jogou lá. Quero ser como eles, como os jogadores lá, como o Neymar ... (Fernando, 15 anos, Escola Estadual de Ensino Médio Danton Correa da Silva, em 03 de abril de 2017). 




Grafico 1 - Clubes Preferidos pelos Jovens. Fonte: KOCH, Identidades em construção

As respostas dos jovens revelam que a atração pelos clubes internacionais de futebol, em detrimento das equipes nacionais e locais, está bastante vinculada a presença das celebridades e craques da modalidade. Portanto, provavelmente os jovens são seguidores dos atletas e não dos clubes em si. É uma situação que somente poderemos medir e comprovar quando estas "estrelas do futebol" se transferirem de clubes. Optam, portanto, no momento, pelos espanhóis Real Madrid e Barcelona, pois estes clubes concentram os principais atletas da modalidade na contemporaneidade.

Os campeonatos Inglês, Italiano e Alemão não estão entre os mais assistidos por esta juventude, mas os times destes países recebem importância e atenção dos 
jovens, muito provavelmente também pela presença de atletas ou até técnicoscelebridades - caso do espanhol Pep Guardiola, atualmente no Manchester City -, ou ainda, pelo desempenho dos mesmos nas competições europeias, como a Champions League e a Europa League, e acabam também permeando os sonhos de muitos jovens. A avaliação é feita pelos professores que convivem diariamente com estes jovens futebolizados.

É a realidade. Pela internet, pelas redes sociais ... O sonho do menino hoje é jogar no Real Madrid ou no Barcelona e antigamente era jogar no Grêmio, no Inter, no Flamengo, no Corinthians ... times que não tem mais este apelo ... Eu acho que é pela, também, por tudo que se apresenta no futebol da Europa. Pela ostentação que tem. São os atletas mais "badalados", são os que ganham mais ... Então acho que isso influencia, na gurizada, a preferencia deles por isso. (Professor André, Escola Municipal de Ensino Fundamental Santa Terezinha, em $1^{\circ}$ de junho de 2017).

0 nosso futebol, de certa forma, acabou perdendo sua identidade, por vários motivos: tanto por estrutura até mesmo pela questão dos ídolos que sem planejamento - vão muito cedo para o exterior. E isso acaba com que o esporte europeu ou internacional, o futebol, tenha uma visisbilidade maior, até por todo investimento que se tem lá. A questão da identidade ela é muito importante. 0 Brasil, no meu entendimento, ele foi perdendo isso pela soberba e por pensar que era só colocar onze [jogadores] que vamos ganhar uma Copa [do Mundo], um campeonato ... E isso [identidade] se perdeu sim. (Professor Cassiá, Coopec - Cooperativa dos Profissionais de Educação de Canela, em 1ํo de junho de 2017).

Um dos professores tocou no tema da identidade, ou na falta de atrativos do futebol brasileiro para "capturar" os jovens, que em busca de referências vitoriosas e bem sucedidas, acabam preferindo os valores que são difundidos pelos clubes estrangeiros. Inegavelmente a cada ano o futebol nacional tem perdido seu status de décadas anteriores junto ao público jovem que, na contemporaneidade, está muito mais exigente, provavelmente impulsionado pelos artefatos midiáticos que permitem o acesso à outras competições esportivas e formas de entretenimento pouco ou quase inacessíveis no passado. 0 fato é que a exigência da juventude por um bom espetáculo, seja esportivo ou cultural, parece ter aumentado na mesma proporção em que os atrativos locais perderam significado para a mesma. Percebo que o fenômeno que ocorre com o futebol, em certa medida, também é observado no basquete e/ou nos shows musicais. 
Outros clubes, com recentes passagens e destaque na mídia - como Palmeiras, Atlético de Madrid, Chapecoense, Monaco e Novo Hamburgo -, também foram citados nessa pesquisa, mais com indices bem menores e, talvez, com o rápido desaparecimento para a juventude futebolizada. As condições encontradas nestas duas últimas questões se encaixam no debate que Hall ${ }^{35}$ propõe no livro $A$ identidade cultural na pós-modernidade. 0 autor afirma que: “[...] as velhas identidades, que por tanto tempo estabilizaram o mundo social, estão em declínio, fazendo surgir novas identidades e fragmentando o indivíduo moderno". ${ }^{36}$ Portanto, seguir muitos clubes de futebol - como é o caso dos jovens estudados na Região das Hortênsias - nos remete a uma fragmentação das identidades.

O sujeito, previamente vivido como tendo uma identidade unificada e estável, está se tornando fragmentado; composto não de uma única, mas de várias identidades, algumas vezes contraditórias ou não-resolvidas. [...] Esse processo produz o sujeito pós-moderno, conceptualizado como não tendo uma identidade fixa, essencial ou permanente. A identidade torna-se uma "celebração móvel": formada e transformada continuamente em relação às formas pelas quais somos representados ou interpelados nos sistemas culturais que nos rodeiam. [...] 0 sujeito assume identidades diferentes em diferentes momentos, identidades que não são unificadas ao redor do "eu" coerente. ${ }^{37}$

\section{O FUTEBOL COMO UM DOS ÚLTIMOS REDUTOS DE IDENTIDADES COLETIVAS MODERNAS NA PÓS-MODERNIDADE}

Ao longo desta pesquisa, defendi e argumentei que os sujeitos na pós-modernidade ao construírem, desconstruírem e reconstruírem suas identidades quantas vezes lhes convierem estão cada vez mais individualistas. Ou seja, há um afastamento ou descaso com as preocupações sócio coletivas de passados distantes ou até recentes. No entanto, ambiguamente, as identidades somente se constituem a partir das possibilidades de identificação e diferenciação de grupos. Portanto, movimentos coletivos - ainda que sejam fugazes, voláteis, tribais e momentâneos são necessários na constituição identitária.

\footnotetext{
${ }^{35}$ HALL. A identidade cultural na pós-modernidade.

${ }^{36}$ HALL. A identidade cultural na pós-modernidade, p. 7.

${ }^{37}$ HALL. A identidade cultural na pós-modernidade, p. 12-13.
} 
Parece-me que o futebol, neste cenário, dispõe de uma condição ímpar. Mesmo permitindo que cada indivíduo livremente escolha seu(s) clube(s) e seu(s) ídolo(s) de preferência e por ele(s) demonstre uma paixão e um amor profundo, há em torno dessa situação a formação de agrupamentos de - no mínimo - seguidores das agremiações e celebridades. Isso porque o ato de torcer torna-se coletivo, mesmo quando estamos sozinhos diante da tevê assistindo qualquer jogo de futebol. Há um amálgama em torno daquela "nação ritualizada instantaneamente". Portanto, a torcida de qualquer time de futebol - sendo efêmera ou não - torna-se um reduto de coletividades e, estas identidades coletivas vinculadas ao futebol mesmo passageiras - ainda apresentam muitos traços e exigências das identidades modernas. Lembro aos leitores que a chegada ou presença de processos identitários pós-modernos - como é o caso da futebolização - não representam o abandono por completo de condições identitárias modernas. Lembro também aos leitores que Giulianotti ${ }^{38}$ aponta a existência de quatro categorias de torcedores na contemporaneidade: fanático, fã, seguidor e flâneur; os dois primeiros com características e mais próximos da condição moderna e os dois últimos com vínculos maiores nas socialidades da pós-modernidade.

Durante as observações, percebi que, é possível que os mesmos jovens que responderam ter preferência pelos espanhóis Real Madrid e Barcelona poderiam ter dado outras respostas há cerca de dois ou três anos atrás e, também, poderão mudar esta preferência por "madrilenhos e catalães" rapidamente. Ou seja, assim que estas equipes deixarem de conquistar os troféus e forem substituídas por outras que obtenham êxitos semelhantes. Portanto, para uma constatação em longo prazo sobre a futebolização e suas produtividades em determinado espaço geográfico - neste caso, na Região das Hortênsias - considero que seja profícua a investigação em períodos superiores há dez anos, possibilitando verificar mais efetivamente esta "navegação" que jovens futebolizados fazem por diversas equipes, conforme as vitórias e derrotas das mesmas, além das trocas que as celebridades também fazem neste circuito do futebol mercantilizado e espetacularizado. As presenças dos brasileiros Neymar e Dani Alves no Paris Saint

${ }^{38}$ GIULIANOTTI. Fanáticos, seguidores, fãs e flâneurs. 
Germain (França), recentemente negociados por Barcelona (Espanha) e Juventus (Itália) respectivamente, talvez só sejam produtivas na captação de seguidores daqui a duas ou três temporadas do futebol europeu. Até lá, outros craques também poderão trocar de clube, emergir, ou até encerrarem as carreiras, o que também acaba por afastar ou aproximar jovens das agremiações estrangeiras. A tradicional "gangorra" da dupla Gre-Nal, ou seja, quando um dos principais clubes do Rio Grande do Sul está bem o outro normalmente está mal, também é fator que contribui neste processo, além do afastamento gradativo dos jovens dos estádios brasileiros devido a violência que permanece ou que por vezes se manifesta nestes ambientes. Enfim, é possível concluir que a futebolização da(s) juventude(s) - por ser um fenômeno pós-moderno - é um processo em constante movimento, assim como outros elementos contemporâneos que contribuem nas fragmentações identitárias desta fase da vida.

\section{REFERÊNCIAS}

ALABARCES, Pablo. Cidadania e narrativas nacionais do futebol argentino contemporâneo. Eco-Pós. Brasil, v. 5 (1), p. 27-36, 2002.

ANDERSON, Benedict. Comunidades imaginadas. São Paulo: Companhia das Letras, 2008.

ANDRADE, Paula Deporte de; COSTA, Maria Vorraber. Usos e possibilidades do conceito de pedagogias culturais nas pesquisas em estudos culturais em educação. Textura, Canoas, v. 17, n. 34, p. 48-63, 2015.

BAUMAN, Zygmunt. Modernidade líquida. Rio de Janeiro: Zahar, 2001.

BAUMAN, Zygmunt. Identidade. Rio de Janeiro: Zahar, 2005.

BAUER, Martin W; GASKELL, George. Pesquisa qualitativa com texto, imagem e som: um manual prático. Petrópolis, RJ: Vozes, 2002.

CANCLINI, Néstor García. Culturas híbridas. São Paulo: EDUSP, 2003.

DAMO, Ariel Sander. Futebol, engajamento e emoção. In: HELAL, Ronaldo; AMARO, Fausto. (orgs.). Esporte e mídia: novas perspectivas: a influência da obra de Hans Ulrich Gumbrecht. Rio de Janeiro: EdUERJ, 2015, p. 49-94.

DEBORD, Guy. A sociedade do espetáculo. Lisboa: Edições Antipáticas, 2005. GIULIANOTTI, Richard. Sociologia do futebol: dimensões históricas e socioculturais do esporte das multidões. São Paulo: Nova Alexandria, 2010. 
GIULIANOTTI, Richard. Fanáticos, seguidores, fãs e flâneurs: uma taxonomia de identidades do torcedor no futebol. Recorde: Revista de História do Esporte, v. 5, n. 1, p. 1-35, 2012.

GURGEL, Anderson. O futebol como agente da globalização. Revista de Economia \& Relações Internacionais, São Paulo, v. 6, n. 12, p. 48-64, 2008.

HALL, Stuart. A centralidade da cultura: notas sobre as revoluções culturais do nosso tempo. Educação \& Realidade, Porto Alegre, v. 22, n. 2, p. 15-46, 1997.

HALL, Stuart. A identidade cultural na pós-modernidade. Rio de Janeiro: DP\&A, 2006.

HALL, Stuart. Sin garantías: trayectorias y problemáticas en estudios culturales. Lima: IEP, 2010.

$\mathrm{KOCH}$, Rodrigo. Marcas da futebolização na cultura e na educação brasileira. Dissertação (Mestrado em Educação). ULBRA, Programa de PósGraduação em Educação, Canoas/RS, 2012.

$\mathrm{KOCH}$, Rodrigo. Identidades em construção: um olhar sobre a futebolização da juventude no Ensino Médio. Tese (Doutorado em Educação). UFSM, Programa de Pós-Graduação em Educação, Santa Maria/RS, 2018.

LIPOVETSKY, Gilles. Da leveza: rumo a uma civilização sem peso. Barueri, SP: Manole, 2016.

LOUZADA, Roberto. Identidade e rivalidade entre os torcedores de futebol da cidade de São Paulo. Esporte e Sociedade. Ano 6, n. 17, 2011.

MORAES, Roque. Uma tempestade de luz: a compreensão possibilitada pela Análise Textual Discursiva. Ciência \& Educação, v. 9, n. 2, p. 191-211, 2003.

SILVA, Juremir Machado. A sociedade midíocre. Porto Alegre: Sulina, 2012.

STEINBERG, Shirley R. Kindercultura: a construção da infância pelas grandes corporações. In: SILVA, Luiz Heron et al. (Orgs.). Identidade social e a construção do conhecimento. Porto Alegre: SMED/POA,1997. 


\section{ANEXO \\ QUESTIONÁRIO - JOVENS FUTEBOLIZADOS}

Nome

(opcional):

Escola:

Idade:

Série:

De que forma você mais costuma acompanhar futebol:

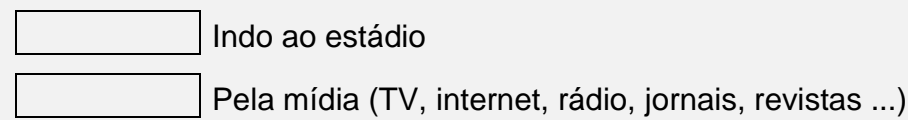

\section{Quantas vezes por ano você vai à estádios de futebol para assistir partidas}

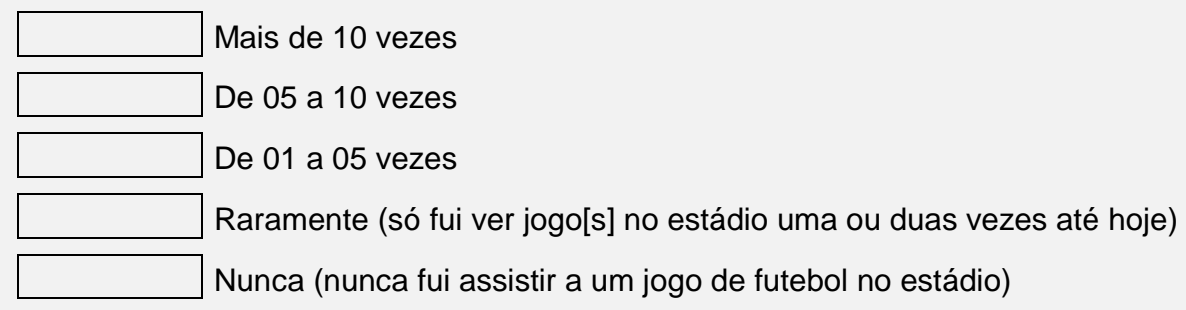

\section{Quantos jogos de futebol você assiste por semana (no estádio ou na tv)}

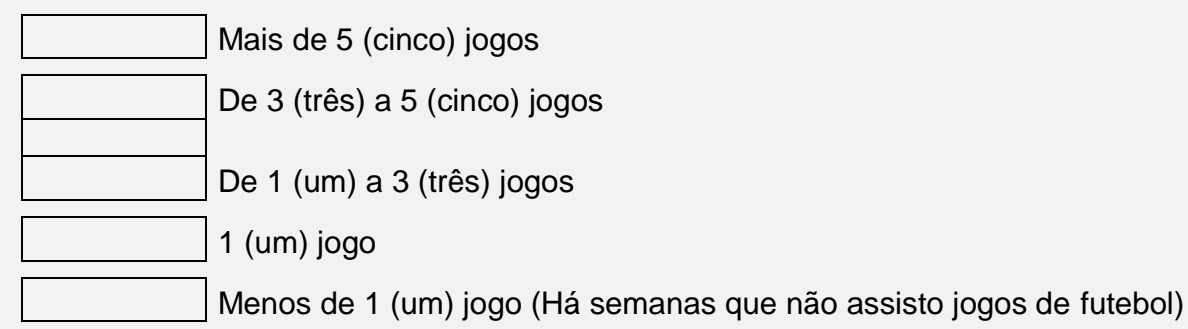

Quais campeonatos/torneios você acompanha? (pode escolher mais de um)

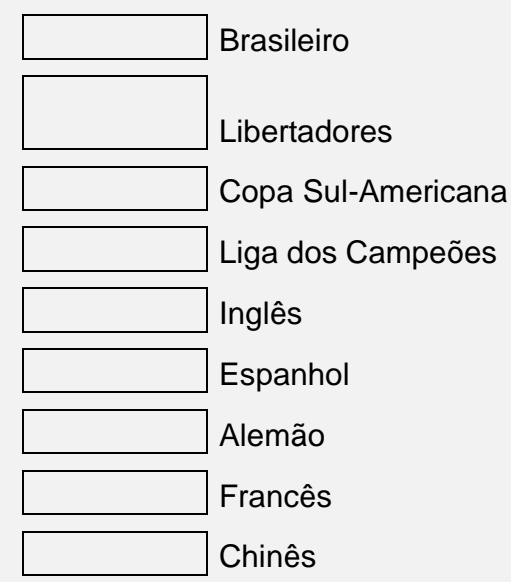

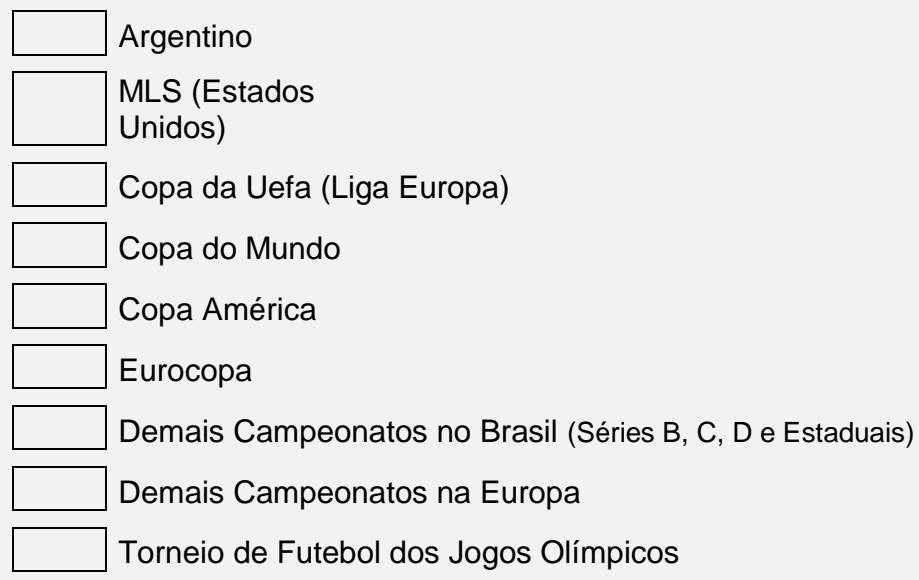


FuLiA / UFMG - Indícios de uma euro-futebolização no Sul do Brasil

Qual(is) destes times você torce? (pode escolher mais de um)

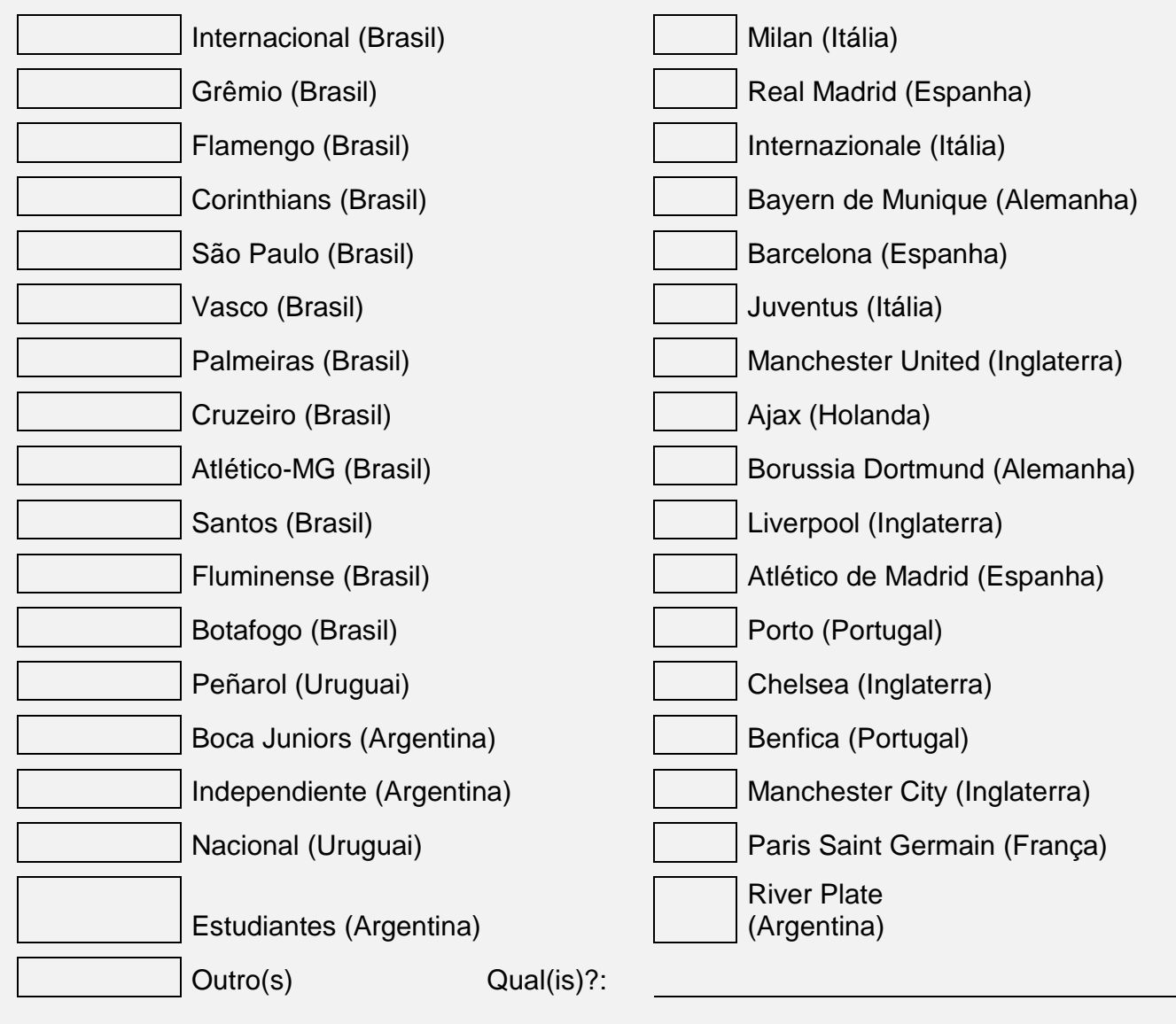

Que produtos relacionados ao futebol você consome? (pode escolher mais de um)

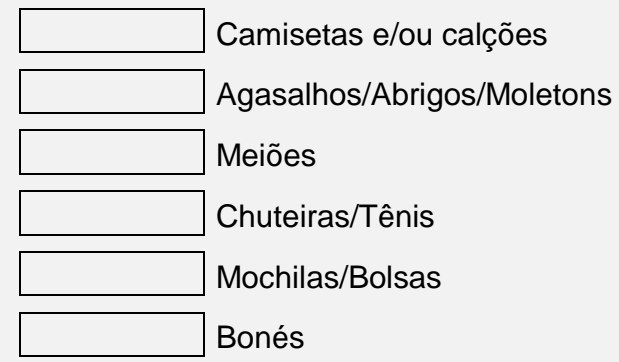

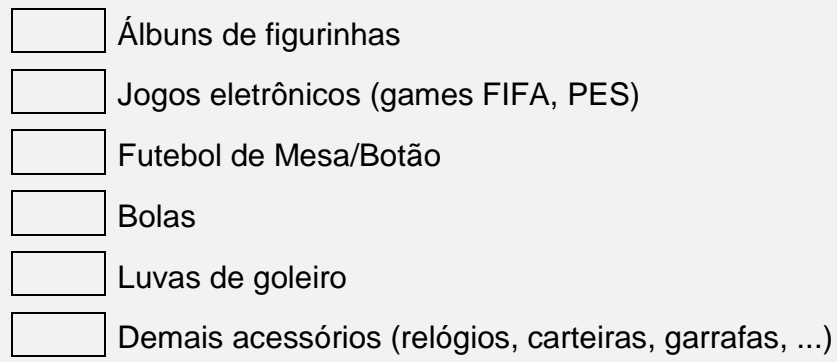

